\title{
ANNUALITY AND MULTI-ANNUALITY IN THE PUBLIC FINANCES OF SELECTED EUROPEAN COUNTRIES - BEFORE COUNCIL DIRECTIVE 2011/85/EU ${ }^{1}$
}

\section{Introduction}

The principle of an annual budget is embedded in the tradition of public finance. For decades, however, there have been concepts of replacing or supplementing it with a principle of multiannual budgetary (financial) planning. In the past, there were attempts at implementing this concept in practice, which have gained in force in the last twenty years. Consequently, at the beginning of the second decade of the $21 \mathrm{st}$ century there already existed complex systems of annual and/or multiannual financial planning in various countries, with different relationships between the annual and multiannual budgetary principles. This study characterizes this situation and its effects. It shows that the recent phenomenon of extending multiannual financial planning has a continuous character and can be treated as an independent principle, right next to the annual budget principle. At the same time, it allows to answer the question of how much justice was there in issuing Council Directive 2011/85/EU of 8 November 2011 on requirements for budgetary frameworks of Member States ${ }^{2}$, which came into force on 11 December 2011, obliging member states to implement it by 31 December 2013. As a result of implementing the directive, every country of the EU should be legally obligated to make multiannual fiscal plans, by preparing a budgetary framework for a minimum period of three years.

The problems discussed above were the subject of study of a special research team $^{3}$, financed by the National Science Centre. The comparative study involved the

\footnotetext{
1 This Article was prepared within the framework of the project financed by the National Science Centre granted on the basis of decision no. DEC-2011/01/B/HS5/03357.

2 Official Journal of the European Union, L 2011 306, further referred to as Council Directive 2011/85/EU.

3 The team consisted of: E. Ruśkowski (project manager), J. Stankiewicz, M. Tyniewicki and U.K. Zawadzka-Pąk.
} 
finances of the EU and ten European countries (Belarus, the Czech Republic, France, Lithuania, Poland, Russia, Slovakia, Hungary, Ukraine, and the UK).

\section{The subject of doctrinal issues}

The doctrine in the second half of the 20th century saw a variety of opinions concerning the relationship between annual budgets and multiannual planning of public finance 4 . This relationship is accurately presented in the views exhibited in Polish studies on public finance and financial law. More than 40 years ago, M. Weralski expressed it like so: "Annual budget legislation ensured a continuity and stability of the parliament's decisions and control in terms of budgetary economy. Today however, there are various reservations to this rule; these include the need for a multi-annual perspective on the development of national financial economy, and the fact that a lot of the expenditure has a continuous character (such as investment expenditure) and that the annual legislation of these expenses creates an atmosphere of uncertainty and makes the normal operation of government institutions difficult. There are postulates of introducing multiannual financial plans working alongside annual budgetary legislation"5. Some years later, J. Harasimowicz emphasized that "for years we have discussed on the necessity of extending the budgetary period. It is stressed that, for example, the one-year period is too short, especially for planning and financing investments, or that the budgetary system lacks an equivalent of multiannual and prospective economic plans, and that budgets for a longer term should be prepared next to annual budgets. It must be noticed though that practice knows only annual budgets. The current attempts at extending the budgetary have period failed (such as the 5-year field budgets in Czechoslovakia, 2-year cluster budgets in Poland), and the concept of a budgetary period, therefore, requires further theoretical studies"6. In the Polish body of work on the subject, $N$ Gajl was a supporter of replacing annual budgets with a multi-annual one ${ }^{7}$. At the time, similar opinions prevailed in other European countries ${ }^{8}$. These views highlighted the fact that such changes would partially be mutually exclusive. On the one hand, it was postulated to replace annual budgets with long-term financial plans (following the competitive principle), and on the other hand, there were postulates of preparing (and possibly implementing) multiannual financial plans alongside annual budgets that would 
support and enhance the latter (following the complementary principle). The most recent literature on this subject emphasizes mainly the advantages of multiannual financial planning, existing alongside with annual budget legislation, stressing the fact that the two do not interfere with each other ${ }^{9}$. Such a solution may have a positive impact on the economic growth of a country by creating resources for implementing structural projects and reforms. It ensures also a specific level of certainty of development for business entities ${ }^{10}$. It has also been noticed that a government's programming abilities increase along with extending the use of medium-term budget legislation ${ }^{11}$. It facilitates and also determines the rationalization of public expenditure, especially when using task based budgeting ${ }^{12}$. From the perspective of the European Union's policy, it also makes it easier for the organization to influence the status and prosperity of public finance in member states ${ }^{13}$.

\section{The possibility of implementing annual and multi-annual budget planning principles (model perspective)}

Theoretically, the relationship between annual budget legislation and the principle of multi-annual financial planning may shape in the following manner ${ }^{14}$.

1) The exclusive existence of an annual budget in financial planning, with the exceptions serving to confirm the annuality principle. In these cases, the principle of a multi-annual budget does not occur in practice.

2) The existence of multi-annual budgets instead of an annual budget. In these cases the budgets implement the multi-annual principle, which exists in conflict with the principle of annuality.

3 ) the side by side existence of an annual budget and multi-annual forecasts or fragmentary projections, reflecting key fiscal categories and influencing indirectly the shape of the budget. This group of measures is called Medium Term Fiscal Frameworks - MTFF.

4) Creation of multi-annual plans for the whole of the public finance sector, including budgetary calculations (assessments) assigned to services or tasks year on year. Sometimes, this applies only to plans at the central level; but

9 V. Babčak, M. Štrkolec, K. Prievozniková, Finančné pravo na Slovensku a v EÚ, Eurokódex, Bratislava 2012, p. 208.

10 M. Sidak, M. Duračinská i in., Finančné právo, C. H. Beck, Bratislava 2012, p. 120.

11 M. Bakeš, M. Karfiková, P. Kotáb, H. Marková i in., Finančni právo, 6 wyd., C. H. Beck, Praha 2012, pp. 109-152.

12 M. Postuła, P. Perczyński (eds.), Budżet zadaniowy w administracji publicznej, wyd. II, Warszawa 2010, p. 34 ff.

13 K. Piotrowska-Marczak, Kondycja finansowa Unii Europejskiej i jej członków w przeddzień przyjęcia nowych ram finansowych na lata 2014-2020, in: C. Kosikowski (ed.), Przyszłość Unii Europejskiej w świetle jej ustroju walutowego i finansowego, Białystok 2013, p. 14.

14 This outline was first presented in: E. Ruśkowski, J. Stankiewicz, M. Tyniewicki, U. Zawadzka-Pąk (eds.), op. cit., pp. 32-33. To prepare it, especially for elements $3-5$, the authors used a formula presented in S. Franek, Wieloletnie planowanie budżetowe w praktyce międzynarodowej i polskiej, in: T. Lubińska (ed.), Kierunki modernizacji zarządzania w jednostkach samorządu terytorialnego, Warszawa 2012, p. 71. 
often these are independent financial plans at the central and local level. These kinds of plans are called Medium Term Budgetary Frameworks $-M T B F$. Such plans exist independently from the annual budget, although they are interlinked in many ways.

5) If multi-annual financial plans mentioned in Point 4 "contain mechanisms aimed to raise effectiveness and efficiency of public finance while measuring the achievement of targets set at the planning stage"15 they may be regarded as Medium Term Expenditure Frameworks - MTEF. These plans can exist alongside the traditional annual budget or the annual task based budget.

\section{Annual and multi-annual financial planning principles in selected European countries}

The above-discussed theoretical model of the relationship between annual budget legislation and the principle of multi-annual financial planning may be associated with the conditions of selected countries at a given time. However, due to the dynamics of the analyzed situation, the attachment of the countries to specific elements of the model will be subject to changes. Poland may serve as a typical example here - its public finance system in the 1990s was based on annual budget legislation with specific exceptions (the first element of the model), in years 20042009 it implemented medium-term financial frameworks (third element of the model), and from 2010 on, thanks to the Multi-Annual State Financial Plan and multi-annual financial forecasts for regional authorities, Poland can be included among countries with medium-term budgetary frameworks (element four of the model). However, classifying Poland as a country with a medium-term expenditure framework (element five) is still open for discussion due to its unfinished reform of task-based budgets.

Due to space limitations, it is impossible to present here the dynamic statuses of the financial systems of all of the studied countries. Therefore, the analysis will be limited to an overview of practical implementations of specific elements of the model, using examples of selected states ${ }^{16}$. This classification involves only historical data, until the end of 2011.

Generally, the exclusive existence of an annual budget in financial planning, with the exceptions serving to confirm the annuality principle (the first element of the model) was a regular practice until the end of the 20th century. The reforms in the UK in 1998 initiated significant changes in the development of multi-

15 S. Franek, op. cit., p. 71.

16 See for example E. Ruśkowski, Zasada jednoroczności budżetu we współczesnych realiach, in: C. Kosikowski (ed.), Prawo skarbowe i prawo finansowe. Szkoły i uczniowie. Księga dedykowana pamięci Profesora Jerzego Lubowickiego, Białystok 2013, p. 183 ff. 
annual financial planning in Europe ${ }^{17}$. The British system is formed in the shape of Spending Reviews, prepared for three years, and since 2010, for the period of four years. The Spending Reviews from 1998 and 2007 had an overall character and are called Comprehensive Spending Reviews. Their preparation involves creating new strategies and determining a hierarchy of priorities for the decade, and a new distribution (allocation) of resources for their realization ${ }^{18}$. Unfortunately, the reforms of British public finance lost their momentum in 2007 with the replacement of the "golden rule" with a more flexible and less restrictive, so-called, temporary operating rule ${ }^{19}$. Although France is usually associated with significant achievements in terms of multi-annual financial planning, which will be discussed further on, specific reforms on the subject were introduced there relatively late, in years 20072008. Some authors highlight that the organic law on financial laws of 2001 (socalled LOLF) further enhanced the annual budgetary principle, which was already well-entrenched in France ${ }^{20}$.

The existence of budgets for a period of more than one year (the second element of the model discussed above) is in practice very rare ${ }^{21}$. The last two decades have not seen a single case of such budget in the surveyed European countries. Among EU member states, the most quoted exception to the annuality principle is Slovenia, whose budget is legislated every two years. Due to the annual nature of budget planning (rolling budgetary planning), even though the budget in Slovenia is legislated every two years, the work on it takes place every year ${ }^{22}$.

Under the influence of ongoing scientific discussions and the impact of the concept of New Public Management ${ }^{23}$, but also because of the requirements of the European Communities (and then the European Union), already in the 1990s some countries used, alongside their annual budgets, multi-annual financial projections, perspectives or forecasts involving specific fiscal categories, directly affecting the shape of the annual budget. For example, Slovakia used them since 1995, and Lithuania used them since 2000, many years before these countries joined the European Union. A prominent example of the existence of a multi-annual financial

17 For more see: U.K. Zawadzka-Pąk, Instrumenty nowego zarządzania finansami publicznymi w Wielkiej Brytanii, in: E. Ruśkowski (ed.), Instrumenty nowego zarządzania finansami publicznymi w wybranych krajach Unii Europejskiej, Białystok 2011, p. $151 \mathrm{ff}$.

18 Cf. E. Ruśkowski, O potrzebie prowadzenia badań porównawczych w zakresie reformy zarzadzania finansami publicznymi w Unii Europejskiej, ze szczególnym uwzględnieniem reform planowania finansowego, in: E. Ruśkowski (ed.), Instrumenty nowego zarządzania finansami publicznymi w wybranych krajach Unii Europejskiej, Białystok 2011, p. $181 \mathrm{ff}$.

19 R. Chote, C. Emmerson, G. Tetlow, The fiscal rules and policy framework, in: R. Chote, C. Emmerson, D. Miles, J. Shaw (eds.), The Institute for Fiscal Studies Green Budget, January 2009, pp. 97-98.

20 See for example L. Saïdj, Brèves réflexions sur quelques moys-clefs de finance publiques pour le future. "RFFP" 2003, no. 82, p. 16.

21 They are discussed by, for instance, P.M. Gaudemet, op. cit., pp. 232-233; T. Lubińska (ed.), Kierunki modernizacji, pp. 69-70, N. Gajl, op. cit., p. 349 ff.

22 M. Stachurska, Procedury budżetowe w wybranych krajach, „Analizy BAS” 2010, no. 18, p. 9.

23 J. Supernat, Administracja publiczna w świetle koncepcji New Public Management, Wrocław 2005; B.G. Peters, J. Pierre, Handbook of public administration, London 2007; T. Lubińska (ed.), Nowe zarządzanie publiczne skuteczność i efektywność, Warszawa 2009. 
planning scheme (in the broad sense) in EU member states included - next to annual budgets - convergence and stability programmes functioning since $1999^{24}$. In principle, member states prepare such frameworks for three years and update them annually. Still, some rules and legal consequences vary between states with derogation (convergence programmes) and other countries (stability programmes). What is also significant here is the binding of public finance of the EU (EEC), planned for a five year period and later for a seven year period, with the public finances of member states. Within the former, the members must "if only to provide relevant data required to prepare multi-annual financial framework, forecast certain financial factors also for periods extending the one-year budget" ${ }^{\prime 2}$. Sometimes this is linked with specific legal requirements (obligations). In recent years, the efforts to rationalize and limit public debt and deficit have also resulted in separate multi-annual programmes and plans within this scope of most European countries. Generally, it may be said that by the end of 2011 most European states did implement various elements of multiannual financial planning, which were linked with and affected their annual budgets in different ways ${ }^{26}$.

The above mentioned elements of multi-annual financial planning (programming) of public finance did not exclude the preparation of comprehensive, multi-annual financial plans in individual countries (element four of the proposed model). The European Community, and later the European Union, encouraged its members to prepare such plans. The same inspiration also came from other European organizations, especially from the International Monetary Fund, the World Bank, or the Organization for Economic Growth and Development (OECD). The European Union (preceded by the European Economic Communities) gave a good example on how to implement these principles in practice. Since 1998, the EU has had a general annual budget and a multi-annual financial framework, both co-dependent and mutually supportive ${ }^{27}$, which will be expanded upon in the following section of the article.

The documents containing multi-annual financial plans or their elements exist in different countries under various names, which is why it is not their name, but rather their character and contents that decide on their importance. We assume that multiannual financial plans are separate documents adopted in a specific legal form, which pertain to the whole public finance sector and contain a set of revenues and expenses (or profits and losses) for a period of at least three years, with an internal distinction

See C. Kosikowski, Prawo Unii Europejskiej w systemie polskiego prawa finansowego, Białystok 2010, p. 62 ff. Ibidem, p. 184.

The details on the states involved in the survey are presented in - E. Ruśkowski, J. Stankiewicz, M. Tyniewicki, U.K. Zawadzka-Pąk, Roczność i wieloletniość finansów publicznych, (ed.) E. Ruśkowski, Warszawa 2014 (in press).

Cf. M. Tyniewicki, Znaczenie klasycznych zasad budżetowych w budżecie ogólnym Unii Europejskiej, in: L. Etel, M. Tyniewicki (eds.), Finanse publiczne i prawo finansowe - realia i perspektywy zmian. Księga Jubileuszowa dedykowana Profesorowi Eugeniuszowi Ruśkowskiemu, Białystok 2012, pp. 214-217. 
into separate years, with an additional division into scope and/or coverage. Such a multi-annual financial plan should essentially have a specific influence on the annual budget (i.e. it cannot be a parallel financial forecast, independent from the annual budget). Having regard to these assumptions, it may safely be assumed that at the time of issuing Council Directive 2011/85/EU (end of 2011), among the surveyed countries, the following countries possessed a multi-annual financial plan: Poland, France, the UK, Slovakia, the Czech Republic ${ }^{28}$ and Russia ${ }^{29}$. For various reasons, documents prepared in other surveyed countries cannot be regarded as multi-annual financial plans ${ }^{30}$.

Multi-annual financial plans in some of the states mentioned above have a task-based character. This is most evident in the case of France, the UK and Slovakia. ${ }^{31}$ From a formal perspective, the Multi-annual State Financial Plan in Poland corresponds to these assumptions, as it includes expenditures with functional divisions and measuring methods for their realization. There is a dose of uncertainty raised here connected with the fact that the reform of task-based budgeting in Poland is not yet complete, the annual budgets are based on traditional principles, and the effects of the task-based budgeting reform will surely influence the properties and structure of the multi-annual financial plan $^{32}$. Multi-annual financial plans in Russia and the Czech Republic on the other hand are more of a traditional character, corresponding to the traditionalist annual budget approach in these countries.

To summarize this part of the analysis it can be said that in recent years the phenomenon of multiannuality in the planning of public finances or their elements became prevalent. At the time of issuing of Council Directive 2011/85/EU (end of 2011), even though there yet was no legal obligation in the EU to do so, many member states did have multi-annual financial plans, and some of them even had task-based multi-annual expenditure plans. Also, these countries evidently show that the annual budgetary principle started to be supplemented by a (legal) multi-annual financial planning principle. This means that in many countries, the principle of

28 See E. Ruśkowski, Roczność i wieloletniość w finansach publicznych Republiki Czeskiej, in: M. Perkowski et al. (eds.), Całowiek i prawo międzynarodowe. Księga Jubileuszowa dedykowana Profesorowi Bogdanowi Wierzbickiemu, Białystok 2014 (in press).

29 Cf. А. Пауль, Долгосрочное бюджетное планирование в Российской Федерации: результаты и тенденции, in: E. Ruśkowski, J. Stankiewicz, M. Tyniewicki, U. Zawadzka-Pąk (eds.), op. cit., p. 295 ff.

30 See for example Л. Абрамчик, Правовые основы составления годового и долгосрочного бюджета в публичных финансах Республики Беларусь, in: E. Ruśkowski, J. Stankiewicz, M. Tyniewicki, U. ZawadzkaPąk (eds.), op. cit., p. 49 ff. and B. Sudavičius, Роль распорядителей бюджетных ассигнований в бюджетном планировании в Литовской Республике, in: E. Ruśkowski, J. Stankiewicz, M. Tyniewicki, U. Zawadzka-Pąk (eds.), op. cit., p. $325 \mathrm{ff}$.

31 For information on France see for example E. Ruśkowski, U.K. Zawadzka-Pąk, Prawne problemy konstrukcji i funkcjonowania budżetu zadaniowego we Francji. Wnioski dla Polski, (ed.) E. Ruśkowski, Białystok 2010; for details on The UK, see U.K. Zawadzka-Pąk, Instrumenty..., p. 151 ff.; for Slovakia cf. V. Babčak, M. Štrkolec, K. Prievozniková, op. cit., p. $208 \mathrm{ff}$.

32 See for example S. Owsiak, Węzłowe problemy i dylematy związane ze stosowaniem budżetu zadaniowego w Polsce, in: B. Woźniak, M. Postuła (eds.), Budżet zadaniowy metodą racjonalizacji wydatków, Warszawa 2012, p. $29 \mathrm{ff}$. 
annual budgetary legislation existed within the multi-annual budgetary or financial frameworks (plans).

\section{Prerequisites for developing multi-annual financial planning before Council Directive 2011/85/EU ${ }^{33}$}

It may be stated, in general terms, that during the whole of the 20th century the principle of annuality in finance was an absolute statutory rule, yet it was more and more often criticized by the doctrine which demanded its replacement (or augmentation) with the principle of long-termism. This state of affairs persisted despite multiple attempts by practitioners to introduce multi-annual frameworks which failed in the end. Although this was due to a number of different reasons, the fact remains that objective negative experiences did not refer to the governmental system in nature - these occurred both in capitalist and socialist countries based on centralized planning. Only towards the end of the 20th century and in the last decade there was a major shift in existing practice both in terms of legal provisions and management methods. Long-termism has been introduced into the legislation and even into the Treaties and Constitution by the European Union and by various European states ${ }^{34}$. The practical management of public finance has also evolved as more and more countries experiment with multi-annual planning and task-based budgets, which in the future should lead to changes in statutory rules and the nature of the plans. Under these circumstances it is important to question the main factors in the development of the principle of long-termism in public finance in the last ten or so years in Europe. Some examples are listed below.

1) Positive experiences of the European Union (European Community) in terms of multi-annual financial planning and resulting increasing demands on member states. Experience in the EU clearly indicates that multiannual budget planning is possible through EU Directives (the Union and its predecessors have been working on this since $1988^{35}$ ) while retaining a general annual budget. ${ }^{36}$ Apart from showing the practical advantages of this type of planning, member states (as well as associated states) are interested in including in their internal calculations multi-annual data

33 This section of the article uses some of the remarks published earlier in: E. Ruśkowski, J. Stankiewicz, M. Tyniewicki, U.K. Zawadzka-Pąk, op. cit., pp. 30-32.

34 Provisions concerning multi-annual planning in the EU were included for the first time in TFUE (Chapter 2 - Multi-annual financial framework); prior to this, the legal basis were multi-agency agreements. Regulations concerning long term programming of finance were also included in the 2008 amendment of article 34 of the French Constitution.

35 The first Financial Perspective concerned years 1988-1992, then following Perspectives were developed for periods of seven years: 1993-1999, 2000-2008, 2007-2013.

36 See, for example, M. Tyniewicki, Programowanie budżetowe w Unii Europejskiej, in: J. Głuchowski, A. Pomorska, J. Szołno-Koguc (eds.), Uwarunkowania i bariery w procesie naprawy finansów publicznych, published by KUL, Lublin 2007, p. $358 \mathrm{ff}$. 
adopted by the Union. Moreover, of direct concern to member states, they are obliged to submit three-year convergence programmes (those states which are included in derogation) or stability programmes and to keep them up-to-date. They may also be included in excessive deficit procedures and therefore be subject to additional conditions ${ }^{37}$. In terms of the requirement for multi-annual financial planning in particular member states, the Union has limited itself to supporting its development until the issuing of Council Directive 2011/85/EU.

2) The influence of the New Public Management (NPM) on the European financial management practice. New Public Management, whose cornerstone ideas had been formulated in the 1940s in the USA, was developed and applied in the UK and several other countries. It was then adopted by the OECD and the European Community. In its political scope, NPM is supposed to ensure better use of public resources and delivery of better public service - things that are universally accepted. According to independent research by C.H. Hood, and D. Osborne and T. Gaebler, this means introducing competitiveness, service delivery standards, objective quality measuring, decentralization and de-aggregation, professional management into the public sector as well as deploying management techniques and methods used in the private sector. ${ }^{38}$ These features in the public sector will always be debatable, especially if introduced too quickly and formally. However, they do have their application in public finance management. Hence the coining of the phrase New Public Finance Management. This is based on defining the tasks and objectives for the public sector and measuring their delivery with the help of objective measuring factors, with the aim of replacing administering of public resources with effective management. Achieving these objectives is aided in an obvious way by the introduction of task based budgets, which must be accompanied by multi-annual financial planning (programming). It is worth noting that although most modern countries are applying some elements of NPM, there are countries like, for example, Germany which have retained their traditional methodology and frameworks of their public sector ${ }^{39}$.

3) Positive experience in a number of countries, including the European Union, in introducing multi-annual public finance. In accordance with a number

Cf. J. Stankiewicz, Procedury prawne ograniczania nadmiernego deficytu jako instrument konsolidacji finansów państw Unii Europejskiej, in: H. Litwińczuk (ed.), lus fiscale. Studia z dziedziny prawa finansowego. Księga pamiątkowa dedykowana Profesorowi Marianowi Weralskiemu, Oficyna Prawa Polskiego, Warszawa 2012, p. $161 \mathrm{ff}$.

38 These features, frequenting in research by various authors, are listed by B. Woźniak, Nowe czy stare zarządzanie publiczne?, in: J. Głuchowski, A. Pomorska, J. Szołno-Koguc (eds.), Główne wyzwania i problemy systemu finansów publicznych, Published by KUL, Lublin 2009, pp. 274-275. 
of authors, it is possible to state that these experiences have originated in the experiments conducted in the USA involving the PPBS method. Its reworking in the 20th century led to the creation of the PPB in the UK, and the RCB in France; however, those first attempts at implementation failed. Still, these experiences were regarded as a useful learning exercise, and citizens and public administrators were being prepared for upcoming changes. It does not come as a surprise, therefore, that the successful introduction of multi-annual financial planning and task based budget in the UK in 1988 sent an impulse for similar changes to be adopted in France (where a task based budget was introduced in 2006 and multi-annual financial programmes in 2008) ${ }^{40}$. France, on the other hand, seems to set the example and be the trigger for the reforms partially introduced in Poland. A positive example within the European Union has been described above.

4) The IT revolution has also been a positive factor in spreading the principle of multi-annual public finance. The influence of the world-wide financial and economic crisis upon these processes is open for debate. The latter is the subject of heated discussion, with completely incompatible arguments, ${ }^{41}$ warning researchers about making rash syntheses.

\section{Council Directive 2011/85/EU as a new premise for developing the multi-annual financial planning principle}

So far, the analysis brings the following conclusions and questions:

1) Recent years have seen a systematic increase of the importance of multiannual financial planning in public finance management in European countries. In some countries, the principle of multi-annual financial planning acquired a legal status, involving in its scope the principle of annual budgetary legislation (the annual budget principle within the framework of multi-annual financial planning). This happened under the influence of numerous experiences and recommendations of the EU, experiences from other countries and public finance management reforms, i.e. substantial and voluntary factors and not legal obligations. This raises the question: was it necessary to use international (EU) legislation to intervene in the development of this principle, or could all this have happened naturally anyway?

See E. Ruśkowski, U.K. Zawadzka-Pąk, Prawne problemy konstrukcji i funkcjonowania budżetu zadaniowego we Francji. Wnioski dla Polski, (ed.) E. Ruśkowski, Temida 2, Białystok 2010 (especially ch. I, pt. 4), p. 36 ff. Cf., for example, S. Owsiak, Sanacyjna funkcja finansów publicznych, in: S. Witeska, S. Wypych (eds.), W poszukiwaniu efektywności finansów publicznych. Księga Jubileuszowa dedykowana Profesor Krystynie Piotrowskiej-Marczak, Published by Uniwersytet Łódzki, Łódź 2009, p. 42. 
Annuality and multi-annuality in the public finances of selected European countries...

2) Although multi-annual financial planning is common in European countries - either in the form of partial financial plans supplementing the annual budget principle or separate multi-annual financial plans within (or alongside) the framework of the functioning of annual budgets - there was an array of various legal and material solutions for the matter. Therefore, it seems that there were premises for unifying these solutions, pushing for implementing a minimum of common standards and definitions. Although Europe-wide (such as the Council of Europe) organizations did not have the relevant legal instruments, such actions could be introduced by the bodies of the EU.

3) It was impossible to illustrate a clear relationship between the development of the multi-annuality principle and the state of public finances in particular counties. The countries where the principle is broadly applied (such as France, Poland, Slovakia, the UK), and those with a task-based budget or at advanced stages of developing one, all have various problems in terms of public finances (the amount of public debt or deficit, the reality of income plans, etc.). This shows that singular solutions, even though they should in principle improve public finance management, may not present the expected results, if they are not involved in an overall, cohesive system. It may well be stated that until the issuing of Council Directive 2011/85/EU, multi-annual financial planning and the problems corresponding to it in member states remained outside of EU policy in terms of the Growth and Stability Pact. It, therefore, comes as no surprise that the reform of the pre-emptive and corrective parts of the pact should also involve problems connected with multi-annual financial planning.

Supporting this idea is the fact that in June 2010, the European Council reached an agreement on the immediate need for increasing the coordination of economic policies among member states that involved reforming the Growth and Stability Pact and budgetary supervision. It was decided in particular: to strengthen the preventive and corrective parts of the Growth and Stability Pact, even by sanctions and proper recognition of the individual situations of particular member states in the euro zone; to pay - in terms of budgetary supervision - much closer attention to the levels of debt and the overall stability of public finance and changes in them; to make all member states implement budgetary principles and medium-term budgetary frameworks conforming to the Growth and Stability Pact within their legal systems; ensure the reliability of statistical data ${ }^{42}$.

42 European Commission. Explanatory memorandum to the proposal for a Council Directive on requirements for budgetary frameworks of the Member States of 29 September 2010, COM (2010) 523 final. 2010/0277 (NLE), Brussels, 29 September 2010 (script), p. 3 Memorandum. 
In terms of detailed information on Council Directive 2011/85/EU it was decided that it cannot be expected that the efficiency of executing the frameworks of budgetary coordination within the Economic and Monetary Union (EMU) will only stem from the regulations enforced by the EU. Due to the peculiar, decentralized budgetary policy of the EU and because of the general need to ensure a national identity with EU regulations, it is essential that the objectives of the budgetary coordination frameworks in the EMU were reflected in national budgetary frameworks. National budgetary frameworks are a set of elements which form a base for managing a national budget. It involves a system of public accounting, statistics, forecasting principles, numerical budgetary rules, budget procedures applied at various levels of the budgetary process and - in particular - medium-term budgetary frameworks, as well as the various relations between various subsections of the public sector. Although the specific needs and preferences of member states have to be respected, some of the criteria seem to be of particular importance, as they mean to ensure a minimum of quality and cohesion within the budgetary frameworks of the EMU. These criteria are the subject of Council Directive 2011/85/EU in terms of national budgetary frameworks that are intended to supplement the reforms of the Stability and Growth Pact. The above mentioned justification for the Commission's proposal also stresses the fact that the national budgetary frameworks should also be supplemented with multi-annual budgetary planning principles, in order to ensure the realization of medium-term objectives on the EU level. ${ }^{43}$ The subject sentence is also important in terms of the deliberation in this article as well as because of the notentirely clear provisions of the Council Directive 2011/85/EU in this scope.

The issuing of the Directive that should have been implemented by 31 December 2013 by EU member states, is an additional direct legal premise to develop the principle of multi-annual financial planning in EU states. By that date, particular countries of the EU should have implemented, among others, the following principle, as expressed in point 20 of the Directive's Preamble: "Although the approval of annual budget legislation is the key step in the budget process in which important budgetary decisions are adopted in the Member States, most fiscal measures have budgetary implications that go well beyond the annual budgetary cycle. A singleyear perspective therefore provides a poor basis for sound budgetary policies. In order to incorporate the multiannual budgetary perspective of the budgetary surveillance framework of the Union, planning of annual budget legislation should be based on multiannual fiscal planning stemming from the medium-term budgetary framework" 44 . This is a good moment to highlight that both the interpretation of the legal wording of this principle as well as its practical realization by particular 
Annuality and multi-annuality in the public finances of selected European countries...

countries (which will change with time and experience) can vary and will require constant and broad study in the future.

\section{Final remarks}

After the dominance of annual budget principle, which lasted until the 1990s, and even though the doctrine saw numerous discussions on the need of implementing multi-annual financial planning (alongside or instead of an annual budget) and had specific practical experiences in the field, at the turn of the century more and more European countries began introducing fragments of multi-annual financial planning to strengthen their annual budgets, and, later, comprehensive multi-annual financial plans. It may well be said that in 2011 it was common for European countries to strengthen their annual budgetary principles with multi-annual financial plans, even though there was no such obligation or standard in international law. Still, it is important to recognize the vast differences in the approaches to this problem between particular countries. Therefore, it seems good that in order to unify the regulations in particular member states the EU decided to issue Directive 2011/85/EU which introduced the minimal standards, requirements, and definitions in terms of medium term budgetary planning. This is, however, both the effect and the cause of issuing the said directive. Its main objective was to introduce medium-term financial planning into the policy of the EU, aimed at coordinating the financial policies of particular members and to increase the supervision over this policy. Also, it is supposed to improve fiscal policies and stabilize the public finances of the EU and of particular member states. Therefore, the provisions of Council Directive 2011/85/EU (including the provisions on multi-annual financial planning) cannot be treated as an end in itself but rather as a measure of implementing more general goals, outlined in the reform of the Growth and Stability Pact, and budgetary supervision. 


\section{ROCZNOŚĆ I WIELOLETNIOŚĆ W FINANSACH PUBLICZNYCH WYBRANYCH KRAJÓW EUROPEJSKICH - PRZED WYDANIEM DYREKTYWY RADY 2011/85/UE}

W przedmiotowym artykule przedstawiono problem stosunku zasady roczności budżetu do wieloletniego prawa finansowego, zarówno w ujęciu doktrynalnym, jak i jego realizacji w zarządzaniu finansami publicznymi poszczególnych krajów. Powstaje $\mathrm{z}$ tego obraz dominacji zasady roczności budżetu do lat dziewięćdziesiątych XX w. oraz jej uzupełniania początkowo fragmentarycznymi, a potem całościowymi wieloletnimi planami finansowymi w późniejszych latach. Analiza sytuacji wybranych krajów europejskich w 2011 r. pokazuje, że wiele z nich ma już wyodrębnione, wieloletnie plany finansowe (a często także budżety zadaniowe) i zasadę roczności budżetu można w nich rozpatrywać w ramach zasady prawnej wieloletniego planowania finansowego. Istnieją jednak poważne różnice między poszczególnymi krajami w tym zakresie. Dlatego wydanie dyrektywy Rady 2011/85/UE z dnia 8 listopada 2011 r. w sprawie wymogów dla ram budżetowych państw członkowskich należy traktować jako nowy impuls rozwoju i ujednolicenia wieloletniego planowania finansowego w skali UE. Wieloletnie planowanie finansowe oraz jego stosunek do roczności budżetu będą jednak odtąd elementem szerszej polityki koordynacji finansowej i nadzoru budżetowego ze strony UE oraz porządkowania zarządzania finansami publicznymi i ich dyscyplinowania w poszczególnych krajach członkowskich.

Słowa kluczowe: roczność budżetowa, wieloletniość budżetowa, średniookresowe ramy budżetowe, wieloletni plan finansowy, Dyrektywa Rady 2011/85/UE

Keywords: budget annuality, budget multi-annuality, medium-term budgetary frameworks, multiannual financial plan, Council Directive 2011/85/UE 